\title{
Acrocomia crispa fruits lipid extract prevents LPS-induced acute lung injury in mice
}

[Extracto lipídico de los frutos de Acrocomia crispa previene el daño pulmonar agudo inducido por LPS en ratones]

\author{
Licet Mena, Roxana Sierra, Maikel Valle, Vivian Molina, Sandra Rodriguez, Nelson Merino, Zullyt Zamora, \\ Victor González \& Jose Alberto Medina
}

\author{
Pharmacology Department, Centre of Natural Products, National Centre for Scientific Research, Havana City, Cuba \\ Contactos | Contacts: Vivian MOLINA - E-mail address: vivian.molina@ cnic.edu.cu
}

\begin{abstract}
The aim of this study was to evaluate the effects of single oral doses of D-005 (a lipid extract obtained from the fruit oil of Acrocomia crispa) on LPS-induced acute lung injury (ALI) in mice. D-005 batch composition was: lauric (35.8\%), oleic (28.4\%), myristic $(14.2 \%)$, palmitic $(8.9 \%)$, stearic $(3.3 \%)$, capric $(1.9 \%)$, caprylic $(1.2 \%)$, and palmitoleic $(0.05 \%)$ acids, for a total content of fatty acids of 93.7\%. D-005 (200 mg/kg) significantly reduced lung edema (LE) $(\approx 28 \%$ inhibition) and Lung Weight/Body Weight ratio (LW/BW) (75.8\% inhibition). D-005 (25, 50, 100 and $200 \mathrm{mg} / \mathrm{kg})$ produced a significant reduction of Histological score $(59.9,56.1,53.5 \mathrm{and} 73.3 \%$ inhibition, respectively). Dexamethasone, as the reference drug, was effective in this experimental model. In conclusion, pretreatment with single oral doses of D-005 significantly prevented the LPS-induced ALI in mice.
\end{abstract}

Keywords: Acrocomia crispa; D-005; Fatty acids; Acute lung injury; Lipopolysaccharide; Mice

Resumen: El objetivo de este estudio fue evaluar los efectos de dosis orales únicas de D-005 (extracto lipídico obtenido del aceite de frutos de Acrocomia crispa) sobre el daño pulmonar agudo (DPA) inducido por LPS en ratones. La composición del lote de D-005 fue: ácido láurico (35.8\%), oleico (28.4\%), mirístico (14.2\%), palmítico (8.9\%), esteárico (3.3\%), cáprico (1.9\%), caprílico (1.2\%) y palmitoleico $(0.05 \%)$, con un contenido total de ácidos grasos de $93.7 \%$. D-005 $(200 \mathrm{mg} / \mathrm{kg})$ redujo significativamente el edema pulmonar $(\mathrm{EP})(\approx 28 \%$ de inhibición) y la relación peso pulmón/peso corporal (PP/PC) (75.8\% de inhibición). D-005 (25, 50, 100 y $200 \mathrm{mg} / \mathrm{kg}$ ) produjo una reducción significativa de la puntuación histológica $(59.9,56.1,53.5$ y 73.3\% de inhibición, respectivamente). La dexametasona, fármaco de referencia, fue efectiva en este modelo experimental. En conclusión, el pretratamiento con dosis orales únicas de D-005 previno significativamente el DPA inducido por LPS en ratones.

Palabras clave: Acrocomia crispa; Ácidos grasos; Daño pulmonar agudo; Lipopolisacárido; Ratones. 


\section{INTRODUCTION}

The acute respiratory distress syndrome (ARDS) was firstly described in 1967 (Ashbaugh et al., 1967) in patients with acute attacks of tachypnea and hypoxia, being considered as a severe particular case of acute lung injury (ALI) (Bernard et al., 1994; Ranieri et al., 2012).

ARDS/ALI causes could be from a multifactorial origin and generally are associated to diffuse alveolar damage characterized by clinical symptoms of dyspnea, arterial hypoxaemia and bilateral pulmonary infiltrates in absence of clinical evidence of left atrial hypertension. Both of them are responsible for thousands of adult and pediatric deaths annually worldwide, showing a significant mortality rate $(30-60 \%$ of all reported cases) (Singh et al., 2014), while the most common initiating event of ALI/ARDS involved: gastric acid aspiration, pneumonia, pulmonary contusion, sepsis, shock, trauma, multiple transfusions, pancreatitis, etc (Matute et al., 2008; Travieso \& Blanco, 2009).

Inflammation is an important etiological factor in the development and progression of this pathology. An acute inflammatory response in the airways causes damage to the epithelium and pulmonary endothelium, with the subsequent release of oxidizing substances and proteases. On the other hand, arachidonic acid derivatives such as prostaglandins, thromboxanes and leukotrienes, are implicated as pro-inflammatory mediators of ALI. Significant modifications in the levels of thromboxanes in tissues, as well as circulating prostacyclines promote the formation of edema and changes in pulmonary perfusion due to the increase in the synthesis of mediators of COX-2 (Min et al. 2012; Howden et al. 2012; Bulmuş et al. 2013).

Up to the present there is no evidence of effective pharmacological therapies to treat ALI/ARDS, which justifies the search for new pharmacotherapeutic strategies as a current issue. Emerging therapies currently under investigation to prevent or treat ALI will provide further strategies to reduce these mortality rates, making a noteworthy emphasis on the natural products. In these sense, medicinal plants play an essential role as an important source of pharmacological active metabolites.

The palm family Arecaceae is a wide group comprising approximately 217 genera and 2,500 arboreal species to be found throughout equatorial, tropical, and subtropical areas of the world (Sosnowska and Henrik, 2009). Palm fruits are an important oleaginous resource for the development of the pharmaceutical and cosmetic industries. The species Elaeis guineensis Jacq, Cocos nucifera L. and Serenoa repens $L$. are widely used for these purposes (Rodríguez et al. 2007; González. and Bravo, 2017; Ghorbanpour et al., 2017). In Cuba this family is represented by a great diversity of species (Muñiz \& Borhide, 1982), Roystonea regia (Cuban royal palm) being a specie widely studied for medicinal uses as antioxidant (López et al., 2009; Rodríguez et al., 2010; Oyarzábal et al., 2011; González et al., 2013), antiinflamatory (Menéndez et al., 2006; Ravelo et al., 2011, González et al., 2013) and in benign prostatic hyperplasia (Pérez et al., 2010; Oyarzábal et al., 2013; Guzmán et al., 2013; Oyarzabal et al., 2015), while other species such as Acrocomia crispa (Cuban belly palm), another Cuban endemic palm, with medicinal potentialities has not been sufficiently studied nor employed industrially before. Up to the present there is no documentation of its use in folk medicine.

D-005, a lipid extract obtained from the fruit oil of A. crispa, contains a reproducible mixture of free fatty acids, mainly lauric, oleic, myristic, and palmitic acids; while stearic, capric, caprylic and palmitoleic acids are present in lower concentrations. (Sierra et al., 2015) Previous studies showed that some of these fatty acids, such as myristic, steraic, palmitic, oleic, and several oily extracts containing these fatty acids inhibited cyclooxygenase (COX) and lipooxygenase (LOX) activities in vitro (Chan et al., 1996; Zhang et al., 2002; Henry et al., 2002; Menéndez et al., 2007).

In consonance with this data, a more recent study demonstrated that D-005 inhibited COX-2 and 5-LOX enzyme activities, with highest affinity for COX-2. The dual inhibition of COX-2 and 5LOX suggested that D-005 could produce antiinflammatory effects (Pérez et al., 2017).

Taking into account the primary role played by the COX-2 and 5-LOX enzymes in the pulmonary inflammatory process involved in the development and progression of ALI (Min et al. 2012; Howden et al. 2012; Bulmuş et al. 2013), it is logical to assume that $\mathrm{D}-005$ could provide a protective effect on ALI due to its antiinflammatory profile dual (Pérez et al., 2017). In addition, ALI is one of the most serious health problems due to its high mortality rate (Singh et al., 2014), and until now is an orphan disease of effective pharmacological therapies, that is, without a cure. So, it becomes justifies characterize the lipid extract of fruits of $A$. crispa and evaluate its relevance in the context of acute lung injury.

Several experimental models and different species of animals in the preclinical evaluation of some drugs have been used extensively to reproduce the essential manifestation and the most 
important events of ALI. However, ALI induced by lipopolysaccharide (LPS) in mice is a classical model being widely developed by the researchers worldwide (Matute et al., 2008; Mena et al., 2016).

In light of these issues, this study was carried out to evaluate the effects of D-005 on LPSinduced ALI in mice.

\section{MATERIALS AND METHODS Extract preparation}

Ripe fruits of A. crispa were collected and authenticated (No. 1982-1031) in the National Botanic Garden (Havana, Cuba). Fruits were dried under shade in a well-ventilated area, powdered with a hammer mill at $2.36 \mathrm{~mm}$, and extracted with n-hexane at room temperature (three extractions of $24 \mathrm{~h}$ ). Solvent was removed at $60^{\circ} \mathrm{C}$ under vacuum, in a Büchi rotary evaporator, and the obtained oil was saponified at reflux with a hydro alcoholic potassium hydroxide solution $(0.5 \mathrm{~mol} / \mathrm{L})$. Afterwards, the fatty acids were released with $\mathrm{HCl}$

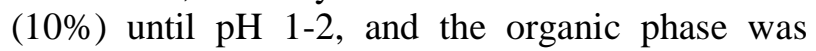
washed with water and dried under vacuum at $110^{\circ} \mathrm{C}$. The product obtained was the D-005 batch used in this study.

\section{Sample preparation for chromatographic analysis}

D-005 batch composition was assessed by a validated specific gas chromatographic method. Fatty acids were prepared for analysis as fatty acid methyl esters using a validated one-step extractiontransesterification method (Rodriguez et al., 2009). Approximately $100 \mathrm{mg}$ of D-005 were placed into a $15 \mathrm{~mL}$ tube with Teflon-lined screw cap. One millilitre of methanol containing $1 \mathrm{mg}$ of the internal standard tridecanoic acid (Sigma-Aldrich, St. Louis, MO, USA), $3 \mathrm{~mL}$ of freshly prepared acetyl chloride (10\%) in methanol and $5 \mathrm{ml}$ hexane were added. The tube was capped, shaken, and incubated at $85^{\circ} \mathrm{C}$ for $30 \mathrm{~min}$ in a dried thermostat, with occasional shaking. After allowing the tube to cool to room temperature, $3 \mathrm{~mL}$ of sodium hydroxide $(2 \mathrm{~mol} / \mathrm{L})$ were added, the tube was shaken in a horizontal shaker for $15 \mathrm{~min}$, and then it was let to stand around two minutes until phase separation. One $\mathrm{mL}$ of the supernatant was carefully transferred to a vial, $1 \mathrm{~mL}$ hexane was added, the vial was capped, shaken for homogenizing, and $1 \mu \mathrm{L}$ was taken for chromatographic analysis.
Fatty Acid Methyl Esters Gas ChromatographyFlame Ionization Detector Analysis

Prepared samples of the batch $(n=3)$ were analysed for fatty acid methyl esters using an Agilent equipment model 7890A (Agilent Technologies, SA) with a BPX-5wide-bore capillary column (30 $\mathrm{m} \times 0.53 \mathrm{~mm} \times d \mathrm{f} 1.5 \mu \mathrm{m}$, SGE, Australia). Injection port and detector temperatures were maintained at $320{ }^{\circ} \mathrm{C}$. Hydrogen was used as the carrier gas at a flow rate of $8 \mathrm{~mL} / \mathrm{min}$. A temperature gradient was used with an initial oven temperature of $120^{\circ} \mathrm{C}(2 \mathrm{~min})$ that increased to 320 ${ }^{\circ} \mathrm{C}$ at $10{ }^{\circ} \mathrm{C} / \mathrm{min}$. Fatty acid methyl esters were identified by their retention times using the FAME standard mix (Supelco, USA) and quantified using Agilent Chem Station software.

\section{Animals and Study protocol}

BALB/c male mice (18-20 g), from the Center for Laboratory Animals Production (CENPALAB, Habana, Cuba) were adapted for 7 days to controlled laboratory conditions: temperature $(25 \pm$ $2{ }^{\circ} \mathrm{C}, 60 \pm 5 \%$ relative humidity and 12 hours' light/dark cycles). Food (rodent pellets supplied by CENPALAB) and water were provided ad libitum. Animal handle was conducted according to the Cuban Code for the Use of Laboratory Animals and ethical principles for animal management No.39/04. The independent ethical board of the Center of Natural Products approved the use of animals and the study protocol.

\section{Substances Preparation, administration and dosage}

D-005, immediately before use was suspended in a vehicle (Tween 65/water, 2\%) and Dexamethasone injectable (Dex) (Carlos J. Finlay laboratory, Havana, Cuba) was used as reference drug. LPS, inductor agent of ALI, (Escherichia coli serotype 055: B5; Sigma Chemical Co., St. Louis, MO), was dissolved in $20 \mathrm{ml}$ of saline solution $(0.9 \%)$.

After quarantine period, mice were randomly divided in eight groups $(n=10)$. Experimental groups were as follows: a negative control group (Tween 65/water oral vehicle administration and $0.2 \mathrm{ml}$ i.p saline solution) without damage induction and seven groups injected with LPS (20 mg/kg, i.p): Positive control (Tween 65/water vehicle), D-005 (5, 25, 50, 100, $200 \mathrm{mg} / \mathrm{kg})$ and Dex $(20 \mathrm{mg} / \mathrm{kg})$ group. Oral administration by gastric gavage of D-005 and Dex were started $60 \mathrm{~min}$ before the intra-peritoneal injection of saline or LPS $(20 \mathrm{mg} / \mathrm{kg})$. 


\section{Experimental Procedure}

One hour before D-005 or Dex administration, except the negative control group, animals were injected with LPS $(20 \mathrm{mg} / \mathrm{kg}$, ip). Twenty-four hours later, anesthesia state was induced by thiopental sodium injection (40 mg/kg, ip) and animals were sacrificed by exsanguinations. Afterwards, lungs and tissue samples were collected to quantify the lung edema (LE) and lung weight/body weight ratio (LW/BW ratio) and to determine the histopathological changes, respectively.

\section{Determination of $L W / B W$ ratio and lung edema}

Mice Body weight (BW) was determined in an analytical balance before the sacrifice, while, lung weight (LW) was immediately determined after to extraction. The LW/BW ratio was calculated taking into account the values of $\mathrm{LW}$ and $\mathrm{BW}$.

LE was determined according to the method described by He et al (He et al., 2014). We evaluated LPS-induced edema by measuring the content of lung water as follow: the left lung was weighed out in analytical balance to obtain the wet weight (WW) and then it was exposed to a temperature of $85^{\circ} \mathrm{C}$ for $48 \mathrm{~h}$ to determine dry weight (DW).

The LE was expressed by the mathematical expression: $\mathrm{LE}=(\mathrm{WW}-\mathrm{DW}) / \mathrm{WW} \times 100 \%$.

\section{Histological analysis}

The lungs were extracted and fixed in buffered formaldehyde solution (10\%). After fixation, the lung tissue was sectioned sagittally and embedded in paraffin. The sections were stained with hematoxylin - eosin (HE). Histological analysis of lung damage was evaluated according to the following variables: neutrophil infiltration, haemorrhages, oedema, exudation, necrosis, congestion, atelectasis and alveolar thickening. The severity of lung injury was evaluated establishing a histological score according to the following criteria: No damage, 0; damage in $25 \%$ of the fields, 1 ; damage in $50 \%$ of the fields, 2 ; damage in $75 \%$ of the fields, 3; diffuse damage, 4 (He et al., 2014).

\section{Statistical Analysis}

Comparisons among groups were done by using the Kruskal-Wallis test and paired comparisons between treated and control groups were done by using Mann-Whitney $\mathrm{U}$ test. The level of statistical significance was set at $\alpha=0.05$. Data were processed with the Statistics Software for Windows (Release 6.1 Stat Soft Inc, Tulsa OK, USA).

\section{RESULTS}

\section{Chemical analysis of D-005 batch}

D-005 fatty acid composition, analyzed by Gas Chromatography (Figure No. 1), was as follows (w/w, \%): lauric $(35.8 \%)$, oleic $(28.4 \%)$, myristic $(14.2 \%)$, palmitic $(8.9 \%)$, stearic $(3.3 \%)$, capric $(1.9 \%)$, caprylic $(1.2 \%)$, and palmitoleic $(0.05 \%)$, for a total content of fatty acids of $93.7 \%$. Other fatty acids were analyzed and quantified, but only the eight major fatty acids, are reported individually. The mean percent coefficient of variance between duplicates for total fatty acids was $0.8 \%$.

\section{Biological effects of D-005 on LPS-injection induced ALI.}

Table No. 1 shows the effects of single oral administration of D-005 on LE and LW/BW ratio in mice with ALI induced by LPS. The i.p. injection with LPS produced a significant $(\mathrm{p}<0.01)$ increase of $\mathrm{LE}$ and $\mathrm{LW} / \mathrm{BW}$ ratio in animals of positive control group compared to animals of negative control group.

D-005 $(5-200 \mathrm{mg} / \mathrm{kg})$ reduced moderately $(\approx 28 \%$ inhibition) the levels of LE, but only the doses of $200 \mathrm{mg} / \mathrm{kg}$, produced a significant reduction $(\mathrm{p}<0.05)$. Furthermore, D-005 decreased the LW/BW ratio, although only the effect of the highest dose $(200 \mathrm{mg} / \mathrm{kg})$ was marked $(75.86 \%$ inhibition) and significant $(\mathrm{p}<0.05)$. Dex $(20$ $\mathrm{mg} / \mathrm{kg}$ ), reference drug, reduced marked $(65.60 \%$ inhibition) and significantly $(\mathrm{p}<0.05)$ not only the $\mathrm{LE}$ but also the LW/BW ratio (58.62\% inhibition).

ALI induction by LPS caused a significant increase of the HS in the positive control group $(\mathrm{p}<0.001)$ compared to the negative control group. The Table No. 2 shows the effects of D-005 oral administration on histological score (HS) in mice with ALI induced by LPS. The lowest assayed dose (5 $\mathrm{mg} / \mathrm{kg}$ ) moderately, but not significantly, reduced the HS while doses of D-005 $(25,50,100$ and $200 \mathrm{mg} / \mathrm{kg})$ produced a significant $(\mathrm{p}<0.05)$ and marked inhibition $(59.9,56.1,53.5$ and $73.2 \%$, respectively) of HS. Dex $(20 \mathrm{mg} / \mathrm{kg})$, reference drug, significantly $(\mathrm{p}<0.05)$ and markedly inhibited HS by $59.9 \%$.

Normal structure of lung tissues was observed in all negative control mice. The Figure No. 2A shows the lung tissue from an animal of the negative control group with a normal distribution of alveolar spaces, also a normal appearance of the squamous epithelium and capillaries without signs of inflammation. By the opposite, lung tissue of all positive controls displayed marked signs of ALI such as severe neutrophil infiltration and alveolar 
thickening almost in $50-75 \%$ of the histological fields (Figure No. 2B).

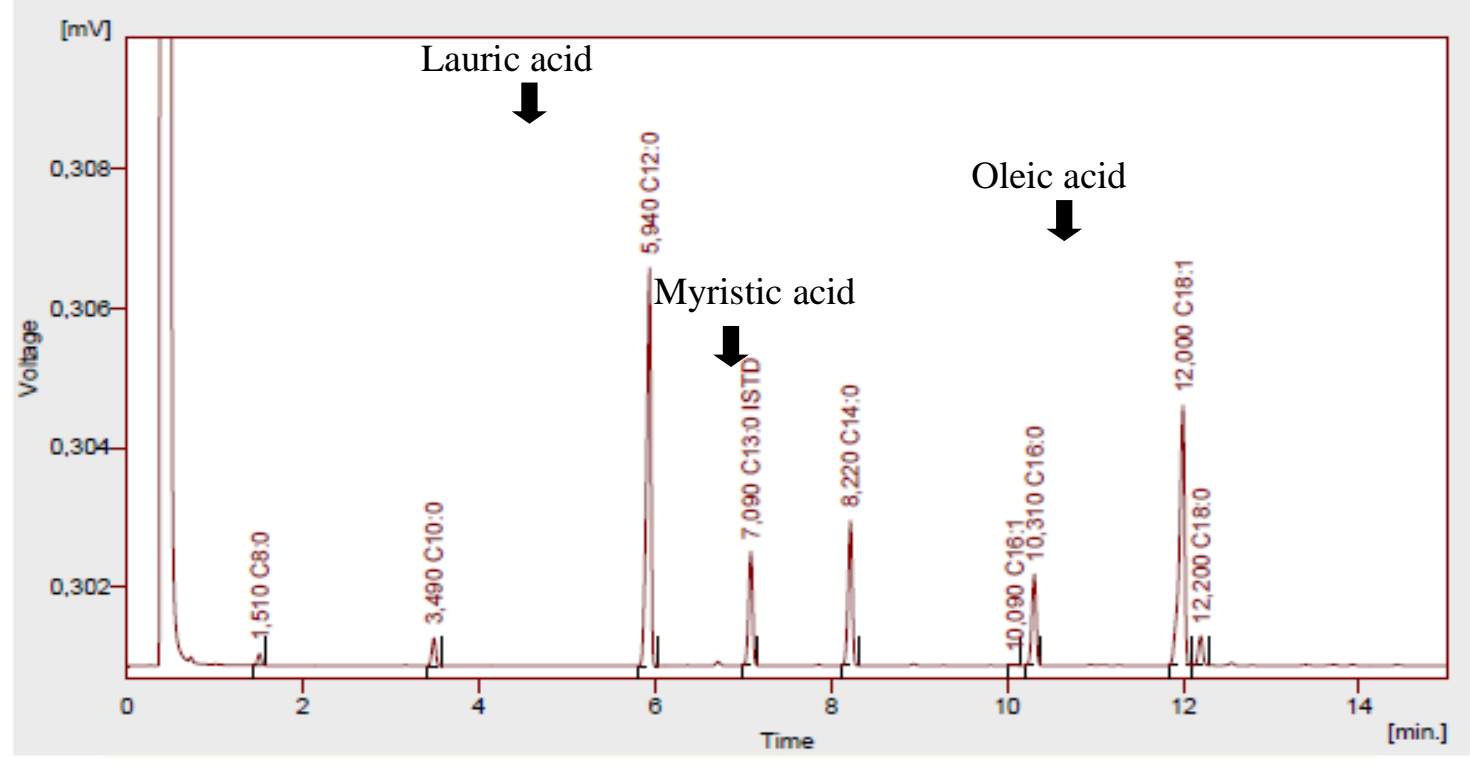

Figure No. 1

Gas Chromatogram of D-005 showing majorly compounds from the total fatty acid composition by black arrows

Table No. 1

Effects of D-005 on LE and LW/BW ratio on LPS induced ALI in mice

\begin{tabular}{l|cccc}
\multicolumn{1}{c}{ Groups } & LE [\%] & I [\%] & LW/BW & I [\%] \\
\hline Negative control (Vehicle) & $78,22 \pm 1,08 * *$ & - & $0,60 \pm 0.08 * *$ & - \\
Positive control (Vehicle + LPS) & $83,86 \pm 1,08$ & - & $0,89 \pm 0,05$ & - \\
D-005 $5 \mathrm{mg} / \mathrm{kg}+$ LPS & $81,81 \pm 0,92$ & 36,3 & $0,78 \pm 0,42$ & 37,9 \\
D-005 25 mg/kg + LPS & $82,24 \pm 0,77$ & 28,7 & $0,78 \pm 0,43$ & 37,9 \\
D-005 $50 \mathrm{mg} / \mathrm{kg}+$ LPS & $82,63 \pm 0,91$ & 21,8 & $0,76 \pm 0,03$ & 44,8 \\
D-005 $100 \mathrm{mg} / \mathrm{kg}+$ LPS & $82,56 \pm 0,92$ & 23,0 & $0,76 \pm 0,04$ & 44,8 \\
D-005 200 mg/kg + LPS & $82,25 \pm 0,46 *$ & 28,5 & $0,67 \pm 0,01 *$ & 75,8 \\
Dex $20 \mathrm{mg} / \mathrm{kg}+$ LPS & $80,16 \pm 0,64 *$ & 65,6 & $0,72 \pm 0,04 *$ & 58,6
\end{tabular}

I: inhibition, LPS: lipopolysaccharide, LE: lung edema,

LW: lung weight, BW: body weight, Dex: dexamethasone.

$* \mathrm{p}<0.01 ; * * \mathrm{p}<0.001$. Comparisons with the positive LPS control (Mann Whitney U test). 
Table No. 2

Effects of D-005 on histological score on LPS induced ALI in mice.

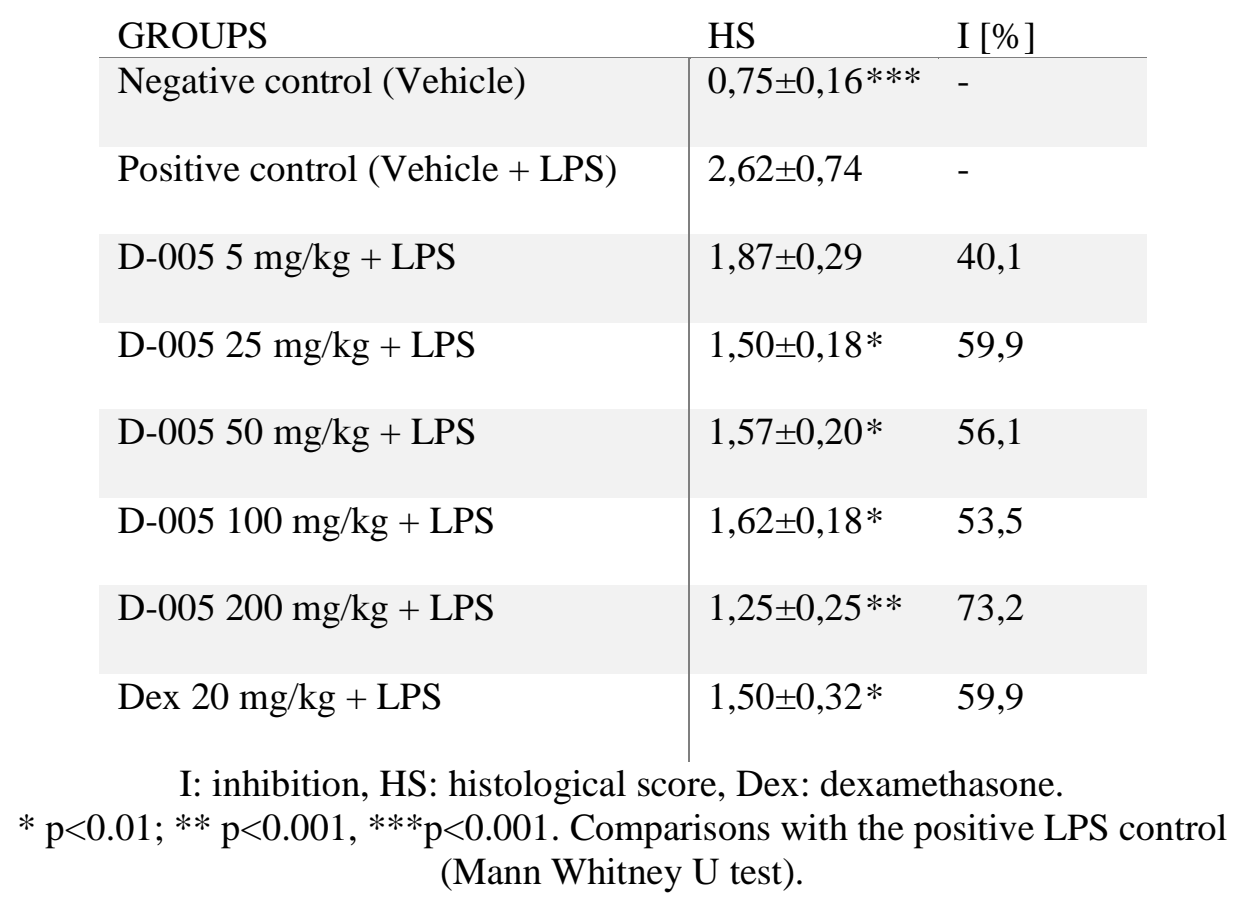

Pretreatments with oral doses of D-005 (25$200 \mathrm{mg} / \mathrm{kg}$ ) ameliorated the pulmonary lesions, while the lowest dose assayed $(5 \mathrm{mg} / \mathrm{kg})$ achieved a slight but not significant inhibition of damage. The Figure No. 2C shows the principal findings observed in lung tissue of animals pretreated with this dose, being neutrophil infiltration and alveolar thickening, evident signs of ALI, while the doses of 25 (Figure No. 2D) and $50 \mathrm{mg} / \mathrm{kg}$ (Figure No. 2E) only showed slight alterations characterized by a poorly neutrophil infiltration.

In contrast, minor damages were found in lung tissues of animals pretreated with D-005 (100 and $200 \mathrm{mg} / \mathrm{kg}$ ). The Figure No. $2 \mathrm{~F}$ and Figure No. $2 \mathrm{G}$ illustrate a prominent attenuation of LPSinduced pulmonary histopathologic findings observed in these D-005 treated groups.

Dex was effective as reference drug achieving a marked and significant inhibition of ALI (Figure No. 2H).

\section{DISCUSSION}

Chromatographic analysis of this D-005 batch confirmed the presence of fatty acids between 8 and 18 carbon atoms, which were identified by comparison of their relative retentions with commercial standards. The free fatty acids composition shows the lauric acid as the major component (35.8\%), followed by oleic acid (28.4\%), and myristic acid (14.2\%). This result is similar to that obtained in a previous study (Sierra et al., 2015). Composition of D-005 differs from those obtained for the oily extracts of the hole fruits of S. repens $(\mathrm{C} 18: 1=43.29 \%, \mathrm{C} 12: 0=26.60 \%$, $\mathrm{C} 14: 0=11.49 \%)$ (Rodríguez et al., 2012) and R. regia $(\mathrm{C} 18: 1=48.50 \%, \mathrm{C} 12: 0=23.30 \%, \mathrm{C} 14: 0=$ $11.00 \%$ ) (Rodríguez et al., 2007), which present higher proportions of oleic acid and lower proportions of lauric acid, although the saturated fatty acids predominate in the three extracts. In addition, it is important to highlight that total free fatty acids content in D-005 (> $90 \%$ ) is higher than those present in the oily extract of other Arecaceae as Serenoa repens (40.7- 80.7 \%) (Habib, 2009).

Arecaceae family is broadly distributed in Cuba and interestingly around $90 \%$ of palms species are endemic (Muñiz \& Borhide, 1982). $R$. regia and A. crispa fruit extracts have a similar fatty acid composition (Rodríguez et al., 2007) and both species have been described as antiinflammatory (Ravelo et al. 2011, González et al., 2013). The compounds mainly differ between species and are found in a variable percentage in oil extracts (Sierra et al., 2014). In accordance, it has been described that some oily extracts containing myristic, steraic, palmitic and oleic acid have an in vitro inhibitory effect on cyclooxygenase (COX) and lipooxygenase (LOX) activities, blockading an important pathway of pro-inflammatory precursors release. (Chan et al., 1996; Henry et al., 2002; Zhang et al., 2002; Menéndez et al., 2007; Pérez et al., 2017) 


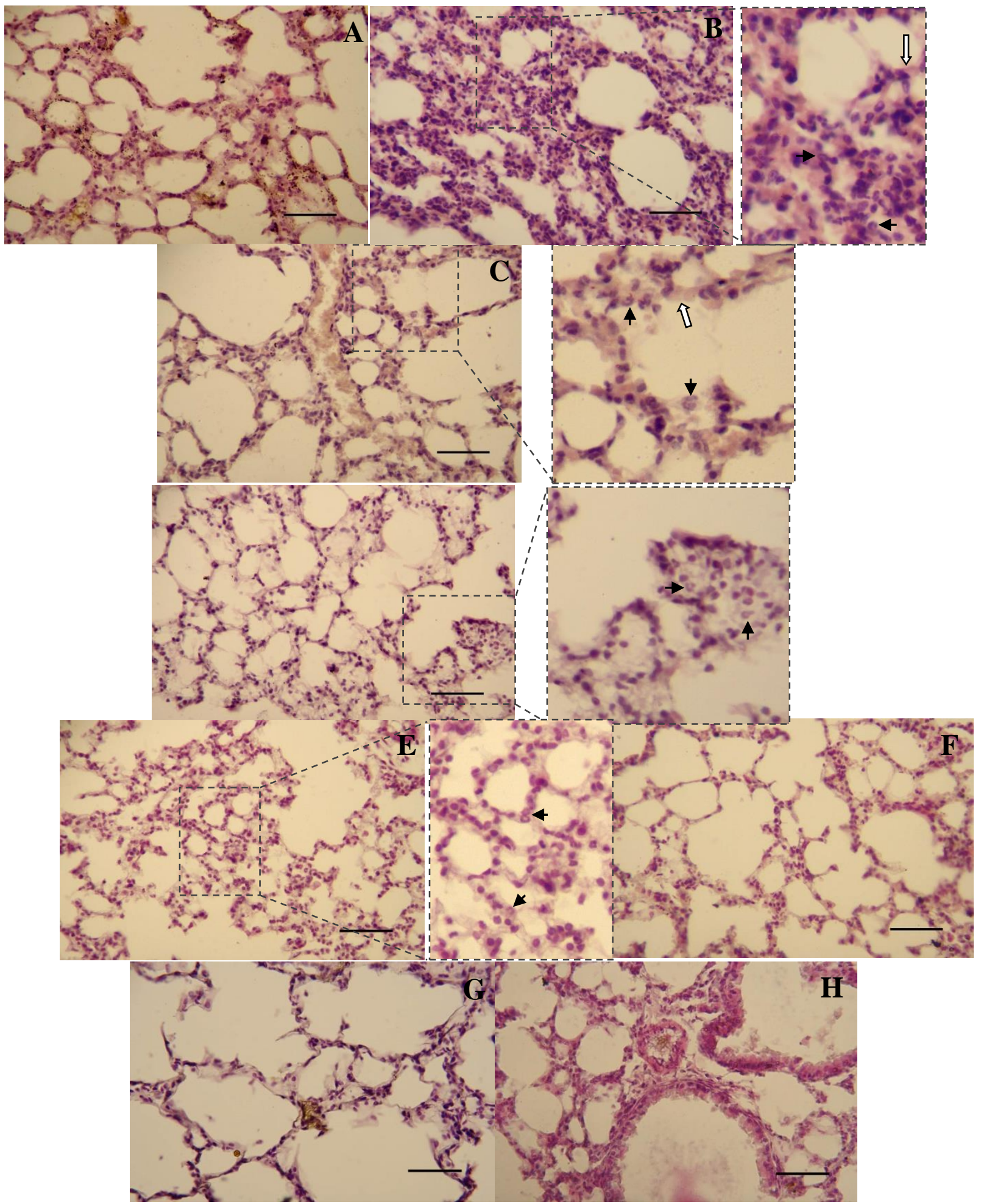

Figure No. 2

Lung sections, H\&E, 40 X. A) Negative control. Normal appearance of alveolar walls without signs of inflammation; B) Positive control showing severe neutrophil infiltration and alveolar thickening; C) D-005 (5 mg/kg) showing neutrophil infiltration and alveolar thickening; D) D$005(25 \mathrm{mg} / \mathrm{kg})$ and E) D-005 (50 mg/kg), showing poorly neutrophil infiltration. F) D-005 (100 mg/kg), G) D-005 (200 mg/kg), H) Dexamethasone $200 \mathrm{mg} / \mathrm{kg}$. In F, G and H a significant attenuation of LPS-induced pulmonary histopathologic changes are observed. Arrowheads: neutrophils, arrows: alveolar wall. The rectangles with dashed lines in B, C, D and E enclose regions that have been magnified to the right of each figure. Bars: $50 \mu \mathrm{m}$. 
Intraperitoneal injection with LPS $(20 \mathrm{mg} / \mathrm{kg})$ induced ALI in mice. ALI was evidenced by a significant increase of LE, LW/BW ratio and the histological changes observed in positive control animals compared to negative control animals. In such regard, it is well known that LPS mechanism to induce ALI involves the LPS binding to specific proteins $(\mathrm{P})$ in pulmonary endothelial cells to form a complex (LPS:P) which activates CD14/TLR4 receptors on monocytes and macrophages promoting the inflammatory mediators release (Yang et al., 1998; Matute et al., 2008) mediated by the Nuclear factor- $\kappa \mathrm{B}(\mathrm{NF}-\kappa \mathrm{B})$ pathway activation. $N F-\kappa B$, a nuclear transcriptional factor, mediates the ALI progression as regulator of different genes encoding cytokines, chemokines, adhesion molecules and growth factors (Blackwell \& Christman, 1997; Lawrence et al., 2001; Kalemci et al., 2013).

Moreover, it has been shown that COX-2 overexpression could be induced by in vitro inoculation of LPS on alveolar macrophages (Hempel et al., 1994; Uhlig et al., 1996), in pulmonary epithelial cells (Mitchell et al., 1994) and rat lung tissue (Chida et al., 1994) promoting the subsequently acute inflammatory response.

In the context of these findings, substances acting on the NF-kB pathway and on the COX-2 overexpression could provide an important pharmacological benefit, by mitigating the inflammatory process involved in ALI.

As can be observed a significant increase of histological markers of lung damage was evidenced in our experimental conditions, being an expected result according to the reports of other authors (Everthart et al., 2006; Kalemci et al., 2013; He et al., 2014). Additionally, Dex $(20 \mathrm{mg} / \mathrm{kg})$, as reference substance, was effective on the analysed variables, which confirms the experimental model validity.

Oral administration of D-005 showed beneficial effects in mice with LPS-induced ALI. D-005 significantly attenuated the presence of neutrophil infiltration and also the alveolar thickening, which are considered very relevant histological evidences of lung tissue injury in ALI (Matute-Bello et al., 2011). The minimum effective dose was $25 \mathrm{mg} / \mathrm{kg}$ since the lower dose tested (5 $\mathrm{mg} / \mathrm{kg}$ ) produced a slight reduction in HS but it was not significant.

On the other side, a maximum effective dose could not be characterized by considering that $200 \mathrm{mg} / \mathrm{kg}$ achieved the highest inhibition on HS, but higher doses were not evaluated in this experimental protocol. Therefore, further studies should elucidate the efficacy of high doses in this ALI model.

Inflammation has been described as an important etiologic factor in ALI initiation (Lee $e t$ al., 2001b; Matute et al., 2008). It is mainly associated to a substantial increase of the mediators of arachidonic acid synthesis as thromboxane and prostaglandins that promote the formation of edema and changes in pulmonary perfusion. Indeed, the increased synthesis of mediators from COX-2 causes activation and mast cell degranulation releasing proteases and chemokines responsible for the increased vascular permeability (PgE2) and produces vasodilatation $\left(\mathrm{PgI}_{2}\right)$, promoting the edema formation. Meanwhile, 5-LOX mediators promotes chemotaxis and the recruitment of macrophages and mast cells to alveolar space (LtB4) promoting the inflammatory infiltration (Guo et al., 2012).

ALI/ARDS are characterized by lung edema due to increased permeability of the alveolar-capillary barrier and subsequent impairment of arterial oxygenation. Lung edema, endothelial and epithelial injury are accompanied by an influx of neutrophils into the interstitium and broncheoalveolar space. Hence, activation and recruitment of neutrophils are regarded to play a key role in progression of ALI/ARDS (Grommes \& Soehnlein, 2011). For these reasons, the inhibition of lung edema and of inflammatory infiltration to the lungs constitutes a possible target for those drugs with potential benefit for the treatment of ALI.

On this regards, previously in vitro studies showed the non-competitive inhibitory effect of D005 on COX-2 and 5-LOX activities (Pérez et al., 2017). Thus, the efficacy of D-005 to reduce LE, LW/BW ratio and attenuate the signs of LPSinduced ALI in mice (neutrophil infiltration and the alveolar thickening) could be associated, at least partially to both enzymes inhibition.

On the other hand, it has been demonstrated that esterified fatty acids as Methyl palmitate (MP), methylester of palmitic acid, attenuate the pulmonary histopathological changes in a murine model of LPS-mediated ALI and such effects involved the inhibition of $\mathrm{NF}-\mathrm{\kappa B}$ activation (Kalemci et al., 2013). Controversially it was demonstrated by Lee et al. that saturated fatty acids could induce the activation of NF- $\mathrm{NB}$ and $\mathrm{COX}-2$ expression in a murine monocytic cell line (RAW 264.7). However, a premise discussed in these work was the fact that unsaturated fatty acids could not only inhibit the saturated fatty acid effect on LPSinduced NF- $\mathrm{\kappa B}$ activation but also the expression of 
COX-2 and other inflammatory markers (Lee et al., 2001a).

Presumably, these findings could clarify why D-005 inhibits the activities of COX-2 and 5LOX and reduces lung damage in the ALI induced by LPS, although the pharmacological mechanism to elucidate its effectiveness has not been fully elucidated.

This study constitutes the first report of the beneficial effects of D-005 on ALI and establishes a fundamental stage to develop new studies and provide new evidences about its effects on this pathological entity.

\section{CONCLUSIONS}

Pretreatment with single oral doses of D-005 markedly and significantly prevented the LPSinduced ALI in mice by reducing not only the histological score but also LE and LW/BW ratio.

\section{REFERENCES}

Ashbaugh DG, Bigelow DB, Petty TL, Levine BE. 1967. Acute respiratory distress in adults. Lancet 2: 319 - 323.

Bernard GR, Artigas A, Brigham KL. 1994. The American-European consensus conference on ARDS: definitions, mechanisms, relevant outcomes, and clinical trial coordination. Am J Respir Crit Care Med 149: $818-824$.

Blackwell TS, Christman JW. 1997. The role of nuclear factor-kappa B in cytokine gene regulation. Am J Respir Cell Mol Biol 1: 3-9.

Bulmuş FG, Gürsu MF, Muz MH, Yaman İ, Bulmuş Ö, Sakin F. 2013. Protective effects of alpha-lipoic acid on oleic acid-induced acute lung injury in rats. Balkan Med J 30: $309-314$.

Chan P, Juei-Tang C, Chiang-Wen T, Chiang-Shan $\mathrm{N}$, Chiang-Ye H. 1996. The in vitro antioxidant activity of triolein and other lipid-related natural substances as measured by enhanced chemiluminiscence. Life Sci 59: 2067 - 2073.

Chida M, Westcott JY, Voelkel NF. 1994. Dexamethasone and a Ca-antagonist fail to suppress lung cyclooxygenase (COX-2) gene expression in endotoxin primed rats. Am J Respir Crit Care Med 149: e429.

Everthart MB, Han W, Sherrill TP, Arutiunov M, Polusukhin VV, Burke JR, Sadikot RT, Christman JW, Yull FE, Blackwell TS. 2006. Duration and intensity of NF-kappa $B$ activity determine the severity of endotoxin-induced acute lung injury. J Immunol 176: 4995 - 5005.

Ghorbanpour M, Hadian J, Nikabadi S, Varma A. 2017. Importance of medicinal and aromatic plants in human life. In Medicinal Plants and Environmental Challenges. Springer, Cham. 1 - 23.

González FJ, Bravo L. 2017. Historia y actualidad de productos para la piel, cosméticos y fragancias. Especialmente los derivados de las plantas. Ars Pharm 58: 5 - 12.

González VL, Sierra R, Mas R, Pérez Y, Oyarzábal A, Rodríguez E, Molina V, Gámez R. 2013. Compounds from the fruits of Acrocomia crispa and Acrocomia aculeata for use against oxidative stress and inflammation. Patent No. wo2013189467.

Grommes J, Soehnlein O. 2011. Contribution of Neutrophils to Acute Lung Injury. Mol Med 17: 293 - 307.

Guo Z, Li Q, Han Y, Liang Y, Xu Z, Ren T. 2012. Prevention of LPS-induced acute lung injury in mice by progranulin. Mediators Inflamm 2012: 1 - 10.

Guzmán R, Illnait J, Mas R, Pérez Y, Fernández L, Mendoza S, Oyarzábal A, Fernández J, Mesa M, Borrero L, Reyes P. 2013. Comparative effects of Roystonearegia (D004) and Saw palmetto lipid extracts on blood oxidative variables in men with benign prostate hyperplasia (BPH). IOSR PHR 3: 1 - 8.

Habib FK. 2009. Serenoa repens: The scientific basis for the treatment of benign prostatic hyperplasia. European Urology 8: 887 893.

He Z, Chen X, Wang S, Zou Z. 2014. Toll-like receptor 4 monoclonal antibody attenuates lipopolysaccharide-induced acute lung injury in mice. Exp Ther Med 8: 871 - 876.

Hempel SL, Monick MM, Hunninghake GW. 1994. Lipopolysaccharide induces prostaglandin $\mathrm{H}$ synthase-2 protein and mRNA in human alveolar macrophages and blood monocytes. J Clin Invest 93: 391 - 396.

Henry G, Momin RA, Nair MG, Dewitt DL. 2002. Antioxidant and cyclooxygenase activity of fatty acids found in food. J Agric Food 50: 2231 - 2234.

Howden R, Cho HY, Miller-DeGraff L, Walker C, Clark JA, Myers PH, Rouse DC, Kleeberger SR. 2012. Cardiac physiologic and genetic predictors of hyperoxiainduced acute lung injury in mice. Am $\mathbf{J}$ Respir Cell Mol Biol 46: 470 - 478. 
Kalemci S, Zeybek A, Intepe YS, Uner AG, Acar T, Yaylali A, Aksun S, Can C, Gulaydin A, Sütçü R. 2013. Methyl palmitate attenuates lipopolysaccharide-induced acute lung injury in mice. Clin Ter 164: e453 - e459.

Lawrence T, Gilroy DW, Colville-Nash PR, Willoughby DA. 2001. Possible new role for NF-kappa in the resolution of inflammation. Nat Med 7: 1291 - 1297.

Lee JY, Sohn KH, Rhee SH, Hwang D. 2001a. Saturated fatty acids, but not unsaturated fatty acids, induce the expression of cyclooxygenase- 2 mediated through Tolllike receptor 4. J Biol Chem 276: 16683 16689.

Lee WL, Downey GP. 2001b. Neutrophil activation and acute lung injury. Curr Opin Crit Care 7: 1 - 7 .

López E, Molina V, Illnait J, Oyarzabal A, Fernandez L, Mas R, Gámez R, Fernández JC, Jimenez S, Mesa M, Hollands I, Mendoza S. 2009. Antioxidant effects of D004, a lipid extract from the Roystonearegia fruits, on the plasma of healthy men. Asian J Androl 11: 385 392.

Matute G, Frevert CW, Martin TR. 2008. Animal models of acute lung injury. Am J Physiol Lung Cell Mol Physiol 295: 379 - 399.

Matute-Bello G, Downey G, Moore B, Groshong S, Matthay M, Slutsky A and Kuebler W. 2011. An Official American Thoracic Society Workshop Report: Features and measurements of experimental acute lung injury in animals. Am J Respir Cell Mol Biol 44: 725 - 738.

Mena L, Cuevas VM, Guerra YP. 2016. Modelos experimentales para la evaluación preclínica de sustancias farmacológicamente activas sobre el Daño Pulmonar Agudo. Rev Cubana Farm 50: 1 $-10$.

Menéndez R, Carbajal D, Mas R, Pérez Y, Molina V, Arruzazabala ML, González R. 2006. Efectos del D-004, extracto lipídico de los frutos de la palma real (Roystonea regia) sobre el granuloma inducido por algodón en ratas y sobre la lipooxigenasa presente en leucocitos polimorfonucleares (PMNs). Acta Farm Bonaerense 25: 213 - 218.

Menéndez R, Mas R, Pérez Y, González RM. 2007. In vitro effect of $\mathrm{D}-004$, a lipid extract of the ground fruits of the Cuban royal palm (Roystonea regia), on rat microsomal lipid peroxidation. Phytother Res 21: 89 - 95.
Min JH, Codipilly CN, Nasim S, Miller EJ, Ahmed MN. 2012. Synergistic protection against hyperoxia-induced lung injury by neutrophils blockade and EC-SOD overexpression. Respir Res 13: 58.

Mitchell JA, Belvisi MG, Akraeasereenont P. 1994. Induction of cyclooxygenase-2 in human pulmonary epithelial cells: Regulation by dexamethasone. Br J Pharmacol 113: 1008-1014.

Muñiz O, Borhide A. 1982. Catálogo de las palmas de Cuba. Acta biol Acad Sci 28: 309 - 345.

Oyarzábal A, Jiménez S, Curveco D, Pérez Y, Molina V, Mas R. 2011. Effects of oral treatment (60 days) with D-004, a lipid extract from Roystonea regia fruits, on rat prostate hyperplasia and oxidative markers. Lat Am J Pharm 30: 368 - 372.

Oyarzábal A, Pérez Y, Jiménez S, Mas R, Molina V. 2013. Effects of D-004, antioxidant and anti-inflammatory substances on testosterone-induced prostate hyperplasia in rats. Oxid. Antioxid. Med. Sci 2: 181 186.

Oyarzábal A, Pérez Y, Molina V, Mas R, Ravelo Y, Jiménez S. 2015. Effects of D-004, vitamin $\mathrm{E}$ and grape seed extract on phenylephrineinduced urodynamic impairment in rats. Trans Androl Urol 4: 391 - 397.

Pérez Y, Oyarzábal A, Molina V, Jiménez S, Curveco D, Mas R. 2010. Estudio del D004 sobre la defensa antioxidante endógena en ratas con hiperplasia prostática inducida por inyección de testosterona. Rev Cubana Farm 44: 221 - 230.

Pérez Y, Oyarzábal A, Sierra R, Mas R., Molina V, Jiménez S, González V. 2017. Inhibition of cyclooxygenase (COX) and 5-lipoxygenase (5-LOX) by D-005 (A lipid extract of Acrocomia crispa fruits). Bol Latinoam Caribe Plant Med Aromat 16: 319 - 328.

Ranieri VM, Rubenfeld GD, Thompson BT, Ferguson ND, Caldwell E, Fan E. 2012. Acute respiratory distress syndrome: the Berlin definition. JAMA 307: 2526 - 2533.

Ravelo Y, Molina V, Jiménez S, Oyarzábal A, Pérez Y, Mas R. 2011. Effect of oral administration of D-004, a lipid extract from Roystonea regia fruits, on xyleneinduced ear oedema in mice. Lat Am J Pharm 30: 1744 - 1748.

Rodríguez E, Marrero D, González V, Sierra R, Adames Y. 2009. Validación de un método por cromatografía de gases para la determinación de los ácidos grasos que 
componen el D-004 ingrediente activo. Rev CENIC Cien Quim 40: 17-22.

Rodríguez EA, González V, Marrero D, Sgambelluri AR., Adames Y. 2007. Fatty acid composition and oil yield in fruits of five Arecaceae species grown in Cuba. $\mathbf{J}$ Am Oil Chem Soc 84: 765 - 767.

Rodríguez EA, González VL, Marrero D, Leiva AT, Vicente R. 2012. Fracciones lipídicas obtenidas a partir de frutos de Serenoa repens recolectados en Cuba. Rev Cub Plant Med 17: 11 - 20.

Rodríguez I, Molina V, Mas R, Illnait J, Oyarzábal A, Mendoza S, Fernández L, Fernández J, Gámez R, Mesa M, Jiménez S, Borrero L, Cruz Y, Perez Y. 2010. Comparison of the antioxidant effects of lipid extracts of Roystonea regia (D-004) and saw palmetto on blood oxidative variables of healthy men. Lat Am J Pharm 29: 1185 - 1192.

Sierra R, González VL, Morales CL, Marrero D, Vicente R, Tamame D, Rodríguez E. 2015. D005, nuevo ingrediente activo obtenido a partir de los frutos de Acrocomia crispa. Rev CENIC Cienc Quim 46: 100 - 101.

Sierra R, González VL, Rodríguez E, Marrero D, Vicente R, Morales CL. 2014. Estudio fitoquímico de los frutos de Acrocomia crispa, palma endémica cubana. Rev CENIC Cienc Quim 45: 41 - 47.
Singh G, Gladdy G, Thomson T, Sen N. 2014. Incidence and outcome of acute lung injury and acute respiratory distress syndrome in the surgical intensive care unit. Indian J Crit Care Med 18: 659 - 665.

Sosnowska J, Henrik B. 2009. American palm ethnomedicine: A meta-analysis. J Ethnobiol Ethnomed 5: 1 - 11.

Travieso MC, Blanco O. 2009. Relación entre mecanismos involucrados y dianas terapéuticas en el síndrome de dificultad respiratoria agudo. Rev Cub Invest Biomed 28.

Uhlig S, Nusing R, von Bethmann A, Featherstone RL, Klein T, Brasch F, Wendel A. 1996. Cyclooxygenase-2-dependent bronchoconstriction in perfused rat lungs exposed to endotoxin. J Mol Med 2: e373.

Yang RB, Mark MR., Gray A, Huang A, Xie MH, Zhang M, Goddard A, Wood WI, Gurney AL, Godowski PJ. 1998. Toll-like receptor2 mediates lipopolysaccharide-induced cellular signalling. Nature 395: 284 - 288.

Zhang Y, Mills GL, Fair MG. 2002. Cyclooxygenase inhibitory activity and antioxidant compounds from the mucelia of the edible mushroom Grifola frondosa. J Agric Food Chem 18: 7581 - 7585. 